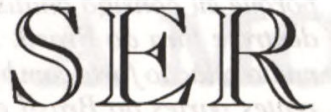

EM

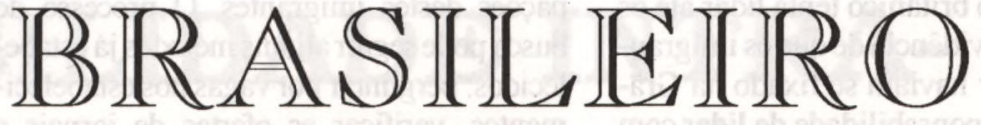

LONDRES

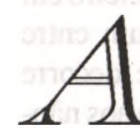

migração de brasileiros para a Inglaterra, em especial para Londres, não é um fenômeno isolado. Ele faz parte de um movimento de procura pelo exterior que vem ocorrendo com maior intensidade desde o final dos anos 80 . Brasileiros jovens, pertencentes ao extrato médio da sociedade de origem e, geralmente, com alguma formação escolar especializada, saem de seu país em busca de algo que acreditam não poder alcançar aí. Em sua maioriavão para os EstadosUnidos, Europa e Japão ${ }^{1}$. A novidade deste fluxo migratório levanta diversas questões. Desde sua inserção no que vem sendo definido como o deslocamento global de força de trabalho de países mais pobres para os mais ricos, aos motivos que levam os brasileiros a saírem, neste dado momento de sua história, de um país tradicionalmente receptor de imigrantes e aos problemas de categorização desses migrantes como permanentes ou temporários. Dequalquer forma há um consenso geral, partilhado tanto pelo senso comum como por estudiosos da vida social, de que se trata de um movimento recente que merece nosso interesse: muitos de nós somos afetados direta ou indiretamente pelo deslocamento de nossos compatriotas ${ }^{2}$.

A preocupação deste artigo $^{3}$ será, não a de localizar o movimento de brasileiros para o exterior no conjunto de relações de mercado de trabalho global, nem mesmo mapear o contexto brasileiro de motivação deste fenômeno, mas sim a de perceber a relação entre o processo de reformulação da identidade dos imigrantes brasileiros e o contexto pluriétnico da cidade de Londres.

\section{RECORTE DO OBJETO}

O material da pesquisa foi coletado durante os anos de 1992 e 1993. O método de coleta constituiu-se em intensa observação participante em diferentes locais de encon- tro desta população na cidade de Londres"; em inúmeras entrevistas semi-estruturadas, registradas com um gravador, e na convivência diária com imigrantes brasileiros nos locais de trabalho e moradia.

No decorrer da pesquisa decidi desconsiderar certas categorias de imigrantesbrasileirosquepossuíam qualquer vínculo institucional com o Brasil segundo o qual poderiam determinar sua situação em Londres e o tempo de sua estadia. Entre estas estão os funcionários da Embaixada, do Consulado e das empresas brasileiras sediadas em Londres. Assim como os estudantescombolsas de estudo financiadas pelo governobrasileiro. Estes eram considerados por meus informantes como, respectivamente, a "elite econômico-política" e a "elite intelectual" da "comunidade brasileira"'. Assim, direcionei minha atenção aos brasileiros que formavam uma "outra" população migrante, a qual não sabia ainda como definir a não ser como "aventureiros".

Estes "outros" imigrantes são pessoas entre $18 \mathrm{e} 35$ anos, da classe média brasileira que vão para Londres em busca de "uma vida melhor". Chegam de diferentes partes do Brasil (especialmente das Regiões Sudeste, Sul e Nordeste) e justificam sua viagem pelos mais diversos motivos: trabalhar, economizar dinheiro, casar, estudar e entrar em contato com um mundo diferente, "moderno".

$O$ leque de possibilidades que a vida em Londres oferece e os problemas que podem enfrentar com o controle da imigração, marca o caráter imprevisível de sua estadia. Estes imigrantes brasileiros não podem ser definidos prematuramente comotemporários ou permanentes porque eles não sabem quandoesevão retornar aoBrasil. Tampouco podem sercaracterizados como "refugiados econômicos" ${ }^{\prime \prime}$, dado que povêm do extrato médio da sociedade brasileira.
Apesar do discurso sobre as motivações da viagem incluir o elemento do acúmulo de recursos assim como o da dificuldade econômica que enfrentam com a "crise brasileira", deve-se ter em mente o significado de tal elaboração. Como exemplo disso, uma das insatisfações pessoais associada àquela "crise" reside na dificuldade, enfrentada pelos jovens, de saírem da casa dos pais. Esta dificuldade implica no retardamento da plena maturidade, processo considerado "natural" de passagem para a vida adulta. Mudar para Londres não implica apenas na possibilidade de fugir da "crise brasileira" ou deacumular recursos; étambém provocar uma passagem simbólica para a vida adulta, éacumular experiência, conquistar determinados status sociais e construir novas identidades, sejam elas pessoais, nacionais ou étnicas.

\section{SER BRASILEIRO EMI LONDRES}

Devido ao caráter multirracial da cidade de Londres, os imigrantes brasileiros entram em contato diário com um leque muito amplo de nacionalidades. Acreditam que os habitantes nativos são tão raros que ser londrino é necessariamente ser de fora, é ser estrangeiro. Este fator fornece um complicador a mais à questão da imigração criando uma dinâmica de interação própria de situações pluriétnicas encontradas nos grandes centros urbanos da Europa.

Londresé sem dúvida um desses centros e abriga uma população de imigrantes, novos ou de segunda e até terceira geração, diretamente vinculada ao passado colonial do Império Britânico?

A ideologia imperial de superioridade racial que orientou a percepção comum sobre os imigrantes, gerou uma atitude discriminatória no convívio cotidiano dos ingleses com imigrantes não-europeus com 
a qual o governo britânico tenta lidar até os dias de hoje. A evidência de que os imigrantes do além mar haviam se fixado na GrãBretanha e a responsabilidade de lidar com sua inserção na sociedade local aliada ao receio dos imigrantes não conseguirem se integrar a ela, mobilizou o governo inglês a enfrentar oproblema. Ele criou uma série de dispositivos legais para tentar minimizar os riscos de ver emergir uma sociedade segregacionista, ondeos problemas das relações raciais setornassem problemas de segurança nacional. Uma das estratégias para lidar com o que é denominado de "relações raciais" reside no acirramento do controle da imigração. Outra é traduzida pela atual ideologia da "igualdade de oportunidades" em nome da qual a etnicidade das pessoas é discriminada em qualquer cadastro oficial. Uma terceira prática éa de financiar instituições filantrópicas para que os próprios imigrantes organizem sua inserção na sociedade local, tais como associações de auxílio legal.

Os imigrantes das ex-colônias do Império e dos países que compõem o Commonwealth of Nations $s^{8}$ ocupam posições bem definidas diante do governo e da população britânica. São gruposde imigrantes reconhecidos como minorias étnicas para os quais o governo dispõe de uma série de prerrogativas não acessíveis aos imigrantes brasileiros.

Um dos efeitos da singularidade da situação dos brasileiros em Londres frente às minorias étnicas, ou seja, aos imigrantes não-europeus com direito à residência no Reino Unido, éindicado pelo fatode que não se concentram geograficamente. A maior parte dos brasileiros encontra-se em posição irregular no que se refere ao seu status legal e uma proximidade regional poderia tornar o controle desta ilegalidade mais fácil para o Home Office. ${ }^{9}$

Geralmente, a natureza da migração dos brasileiros para Londres é solitária: são pessoas solteiras cujos familiares ficam no Brasil. Caso venham acompanhados, o são por amigos que embarcaram na mesma aventura. Os únicos entes familiares mais comuns são os irmãos. Assim, as redes de amizade adquirem papel crucial na organização da vida cotidiana desses brasileiros, tanto no que diz respeito ao auxílio mútuo quanto aos conflitos nelas gerados, marcando fronteiras fluidas entre grupos de cooperação e de concorrência.

O trabalho é uma das principais preocu- pações destes imigrantes. O processo de busca pode seguir alguns métodos já estabelecidos: perguntar por vagas nos estabelecimentos, verificar as ofertas de jornais e revistas, ir a um Job Centre ${ }^{10}$ ou, mais comumente, pedir ajuda aos amigos.

É principalmente no mercado de trabalho não-especializado, "destinado aos imigrantes irregulares"' (Home Office, 1993), que os brasileiros vão encontrar emprego. Dentre eles destacam-se as tarefas de lavadores de pratos, atendentes em restaurantes e em lojas, babás, faxineiros, empregadas domésticas, trabalhos na construção civil e em algumas fábricas.

Aqueles que conseguem trabalho sozinhos vão mais tarde ajudar outros brasileiros, indicando-os aos seus empregadores. $\mathrm{O}$ contato entre amigos é considerado pelos brasileiros como o modo mais eficaz de procura de emprego. As declarações de um informante demonstram isso:

'Sem sobra de dúvida, amigos acabam sendo responsáveis por $90 \%$ dos empregos que o estrangeiro possa encontrar... é de importancia vital reconhecer que para que se tenha uma estadia longa e feliz, é necessário que sejam feitas boas amizades com seus compatriotas." (Motta, 1991)

Assim, vãosendo criadosambientes onde trabalham mais de dois brasileiros. Encontrei um bom exemplo deste fenômeno através de um de meus informantes que havia se empregado numa fábrica de molduras. Evandro não sabe precisar quem ou em que momento o primeiro brasileiro foi trabalhar nesta fábrica. Quando foi levado por um amigo, com quem dividia um apartamento, já haviacerca de 5 brasileiros lá trabalhando. Um ano depois, na mesma época em que me concedeu uma entrevista, os brasileiros eram 12. A relação entre estas pessoas ultrapassava os limites sociais da fábrica. Muitos moravam e se entretiam juntos: organizavam festas, jogavam futebol e praticavam capoeira.

Nos diversos ambientes de trabalho e formas de moradia os imigrantes brasileiros convivem com outros brasileiros originários de diferentes locais do Brasil. Deste fato surge a percepção de que sua estadia em Londres lhes proporciona maior conhecimento de seu próprio país. Determinadas características regionais são catalogadas de acordo com os brasileiros com quem se convive. A declaração de um dos meus informantes é bastante indicativa:

“Eu me sinto mais brasileiro hoje em dia porque eu consigo analisar os brasileiros dentro e fora do Brasil. Aqui a gente tem muita relação forte com brasileiros de diferentes partes do Brasil e hoje eu consigo entendê-los mais do que no Brasil. Lá eu falava que era gaúcho, mas eu conheci muitos gaúchos estranhos aqui. Hoje eu falo que sou brasileiro. Eu me dou muito com cariocas, mineiros e até paulistas. Gosto muito dos cariocas porque sãoabertos para dizer o que pensam e mesmo de si. Nordestino já é mais dificil porque eles têm muita mentira amarrada. "' (Evandro, 1992)

A acepção de que se é mais brasileiro em Londres do que no Brasil é comum entre meus informantes. Ela, claramente, decorre da situação de contraste em relação aos nãobrasileiros, mas também, e muito interessantemente, de um certo processo de nivelamento que em dados momentos promove a associação de brasileiros que não se encontrariam se estivessem em seu país. Seja devido a diferenças de status socioeconômico ou à separação regional.

O nivelamento social ocorre de forma um tanto complexa. Dizer que há uma certa simetria de status não significa afirmar que todos os brasileiros se consideram iguais em Londres. Há significativa heterogeneidade: valores, motivações e interesses contraditórios; distinções em termos de origem, poder aquisitivo e empreendimentos diferenciam as pessoas dentro do conjunto de imigrantes brasileiros em Londres.

Porém, devido ao fato da maior parte de meus informantes estar inserida no mesmo mercado de trabalho não-especializado, ou de já ter passado pela mesma experiência, ocorre uma certa redefinição de valores sociais. Os padrões segundo os quais os imigrantes se movimentam em Londres são determinados por um conjunto de fatores relativos a situações específicas. Ao mesmo tempo os padrões de comportamento trazidos de sua vivência no Brasil também informam suas ações. Diferentes signos evalores sociais serão ativados em situações também diversas. É neste sentido, relativo à dinâmica de formação de novos padrões assim como a reafirmação de outros antigos próprio das experiências migratórias -, que os brasileiros produzem para si novas identidades.É neste sentido, ainda, que é diferente ser brasileiro no Brasil e em Londres.

Assim, Evandro elege os elementos de distanciamento e de aproximação que definem sua própria identidade de brasileiro. Os gaúchos que encontrou em Londres possuí- 
am motivações e valores diferentes dos seus e eram definidos por elecomo pessoas que só querem se dar bem. Evandro associa sua brasilidade aos amigos paulistas, mineirose cariocas, com quem partilha uma determinada visão de sua experiência de migração e para quem as relações de amizade são importantes. Ao mesmo tempo, acredita que as qualidades pessoais não sejam totalmente marcadas pelaorigem regional porque "tem gentefina egente boba em todosos lugares". Assim como existem brasileiros e brasileiros.

Os imigrantes criam redes distintas de relação entre si e nem todos os compatriotas são bem vindos a estas redes. Apenas os amigos nos quais se confia. Existe muito medo de que outros brasileiros tentem concorrer seja pela posição de trabalho ou pelo lugar de moradia. Existe a crença, jamais comprovada, de que estes outros, falsos amigos, denunciem brasileiros em situação irregular ao órgão de controle da imigração (Home Office) por inveja ou cobiça. Estes "outros brasileiros" alimentam o imaginário coletivo desta população de imigrantes como depositários das qualidades negativas atribuidas ao " povo brasileiro"' em geral. Nunca são identificados pessoalmente porque, na realidade, consistem no "tipoideal" do brasileiro sacana ${ }^{11}$.

O exemplo da fábrica de molduras onde Evandro trabalha é muito interessante para a observação do fenômeno de criaçãode rede de relações sociais tanto entre os trabalhadoresbrasileiros, que por suavez trazem outros agregados, quanto de relações entre estes e os operários de outras nacionalidades. $\mathrm{Na}$ realidade a fábrica ilustra bem o caráter pluriétnico da cidade de Londres: a existência de pequenas redes de relações estabelecidas por diferentes populações migrantes e a relação entre estas eas redes de outros nacionais. Na fábrica de molduras, além de brasileiros, trabalhavam imigrantes africanos, em sua maioria ganenses, e irlandeses. A relação entre os brasileiros e os ganenses estabelecia-se, principalmente, durante as partidas de futebol organizadas durante os intervalos para o almoço. $\mathrm{O}$ futebol era um dos elementos identificados pelosoutrostrabalhadores comoum diacrítico da identidade nacional dos brasileirose estes eram tomados como naturais amantes do jogo. Por isso os brasileiros eram sempre esperados para o início das partidas. A comunicação, o entendimento, enfim, a troca social entre os dois grupos dava-seatravés do futebol da hora do almoço, e nesta troca a primazia era dos brasileiros.

Os ganenses não partilhavam de outras situações sociais com os brasileiros e ao perguntar o motivo de tal limite a um informante este explicou-me que a maior parte dos ganenses possuía família e por isso as formas de lazer nos finais de semana eram diferentes. Já os irlandeses acompanhavam os brasileiros em outras ocasiões, especialmente nas festas:

"'Os africanos sãodo TerceiroMundo como a gente, mas no fim das contas a gente tem mais coisas para trocar com os irlandeses do que com os caras de Gana. Sei lá por que. Achoque é porque eles têm mulheres efilhos aqui. Os irlandesesé tudo rapaziada. ' (Leo, 1993)

Esta declaração demonstra os elementos considerados pelos brasileiros como importantes para a possibilidade de aproximação maior com os irlandeses: mesma faixa etária e mesmos interesses de lazer. Demonstra ainda a diferença do caráter migratório dos trabalhadores ganensese dos brasileiros. Os primeiros levaram suas famílias eo trabalho possibilita o sustento deste núcleo familiar e da própria experiência de migração. Eles se enquadram numa imagem de imigrante que os brasileiros recusam para si mesmos e que está associada ao significado do próprio termo para estes. Dificilmente os brasileiros utilizam a categoria de imigrantes para se definirem como população estrangeira em Londres. Este termo é vinculado às pessoas originárias das ex-colônias do Império Britânico e dos países do Commonwealth. Seu processo migratório é compreendido pelos brasileiros como uma mudança mais profunda do que a que estes fazem. Estariam vindo com suas famílias para se estabelecerem no Reino Unido indefinidamente e cuja perspectiva de trabalho não escapa do mercado não-especializado. Para os brasileiros sua situação de mão-de-obra não-qualificadaéprovisória, seja porqueplanejam retornar ao Brasil, seja porque desejam estabelecerse em Londres num setor profissional mais especializado.

Já os amigos irlandeses vestem a imagem de um grupo social ao qual os brasileiros constroem uma equivalência. Uma vez resolvido o problema legal do visto de residência os brasileiros acreditam que têm tantas ou mais chances de sucesso no mercado de trabalho, e no seu processo de inserção na sociedade inglesa, que os irlandeses. Os brasileiros acreditam que trazem consigo uma habilidade de adaptação maior do que a dos irlandeses que é relativa ao seu " "caráter nacional'".

"O brasileiro chega aqui sem permissão,
sem falar a lingua e se descola. Essa coisa
de se descolar faz muito parte da cultura.
brasileira. Então, se a recessão no Brasil é
bem pior do que a daqui, a atitude da gente
é muito mais positiva. Porque o Brasil está
acostumado a cair e levantar sempre. O
brasileiro tem mais jogo de cintura para
superar os problemas e acaba trabalhando
mais e chega mais firme onde planejou do
que esses caras." (David, 1992)

No processo da interação social os brasileiros empreendem esforços contínuos de classificação e diferenciação. Eles não se satisfazem em serem identificados com 0 "'outro"' por excelência do universo simbólico inglês, fundado na ideologia de sua hegemonia racial segundoaqual posicionam os imigrantes originários de suas ex-colônias. Os brasileiros consideram-se pessoas educadas, cultas e, inclusive, cujo país de origem ocupa uma posição superior no contextolatino-americano: oBrasilévisto como um país mais forte economicamente, independente e mais desenvolvido do que seus vizinhos continentais.

Neste sentido, osbrasileiros não se aproximam nem dos imigrantes africanos, indianos, paquistaneses, kurdos, europeus do Leste, nem de qualquer outro que identifiquem como imigrantes "pobres":

"Eu gosto de ser brasileiro. Pelas qualidades irreverentes, é um povo alegre, até a pobreza no Brasil é mais colorida e alegre. Tem of fato de ser mais exótico. Se você disser que é uruguaio não tem appeal nenhum, ou colombiano. O brasileiro é o único que diz que é brasileiro, os outros dizem que sãosul-americanos." (Tito, 1993)

Ao mesmo tempo que os brasileiros rejeitam essa aproximação com os imigrantes (e como os refugiados políticos) que conformam as minorias étnicas, ela também é enfatizada pelo Home Office: os brasileiros são considerados como imigrantestemporários, que não formam uma "comunidade" muito coesa, originam-se do extrato médio da sociedade brasileira e são, em sua maioria, de origem européia. Devido a estes fatores o fenômeno da migração de brasileiros ao Reino Unido não parece apresentar um grande problema para as autoridades do controle daimigração, especialmentesecomparado àqueles impostos pela acolhida de milhares de refugiados recentes (kurdos e europeus do Leste, por exemplo). Ainda 
mais, acredito que os viajantes brasileiros constituem um tipo de imigrante "conveniente" ao mercado local de trabalho não especializado. É neste sentido, aos olhos das agências governamentais do país receptor, que estes imigrantes são reconhecidos, especificamente, como mão-de-obra.

No processo contínuo de confronto com tantas alteridades a imagem que os brasileiros fazem de si mesmos como coletividade é afetada. Características que consideravam como relativas à ordem natural das coisas sãodesmascaradas e, então, vinculadas à sua identidade brasileira. Descobrem, assim, o quanto são mesmo brasileiros: a declaração "eu só descobri que sou muito brasileiro aqui", é recorrente. A imagem própria é suspensa, é confundida no contraste com os "outros". A questão " afinal como sou eu?'” inicia o processo de criação de um modo de serbrasileiro fora do Brasil, maisespecificamente, em Londres.

Ao mesmo tempo grande parte dos meus informantes descobre que é "cidadão do mundo". Acredito que esta formulação está ligada ao caráter cosmopolita de Londres que oferece aos brasileiros o encontro com diversos aspectos do globo, através, não apenas de seus imigrantes, mas também dos bens culturais que expõe. A construção do serbrasileiroemLondres se estabelece, também, nesta relação de interdependência com as "alteridades", numa situação ambígua entre a especificidade - especialidade - de ser brasileiro e a ambição de ser cidadão do mundo.

A auto-representação dos brasileiros navega numa certa confusão; por um lado o Brasil éum paísde belezas exóticasede povo feliz, conhecido internacionalmente por sua música popular e pela exuberância de suas mulheres. Por outro lado, a ameaça de extinção da sua fauna e flora, a acusação de chacinadores decrianças de rua, a impagável dívida externa que arruina a economia do país e o extermínio dos povos da floresta, características que entram no discurso dos europeus ao definirem o Brasil e os brasileiros, fornecem subsídios para que estes europeus reafirmem a "inferioridade" de mais estegrupode imigrantes. Num conflitocíclico de sentir-se superior aos "imigrantes pobres" (incluindoaíalguns de seus compatriotas), os brasileiros empenham-se numa procura ambígua de se aproximarem dos estrangeiros europeus que moram em Londres - especialmente italianos, franceses e espanhóis -, de absorverem o que de "civilizado" a cidade européia mais cosmopolita tem a oferecer e, acima de tudo, de tentar reconstruir uma identidade brasileira que se adeque à sua nova condição pessoal de imigrante. A experiência de ser brasileiro em Londres abrange a totalidade de desejos e expectativas deste novo estilo de vida:

"Eu vim para consquistar meus ideais. Desafiar a mim mesmo. Para colocar em prática as experiências da vida que tive no Brasil. Vim para me educar, para crescer como ser humano, para explodir os limites domeu potencial, para sairda barra da saia da minha mãe, para ter uma independência financeira, social e emocional. Vim para aprender novas linguas, conhecer novos lugares, novas pessoas, novas culturas $e$ novas raças. Vim em busca de um mundo melhor para mim. (...) Vim para vencer!". (Motta, 1991)

-Angela Torresan é mestre em Antropologia Social, Museu NacionaLUFRJ e doutoranda em AntropologiaSociale Visual, UniversidadedeManchesterInglaterra.

\section{NOTAS}

1) Não existem dados estatíticos que informem quantos brasileiros saem do Brasil com infuito de se estabelecerem no Exterior, tampouco para que paises se dirigem. A percepção do vulto deste fenômeno ocorre através da experiência dos brasileiros que partiram e de seus familiares e amigos que ficaram. Os primeiros, ao chegar no pais de destino, logo percebem que não foram os únicos a se deslocar, quando já não vão seguindo a carreira de uma cadeia de migrantes. Os segundos sempre conhecem um outro brasileiro que também saiu do país. Em seguida, os meios de comunicação se dão conta de que estão diante de um fenômeno social novo e se adiantam em veicular o debate social sobre o movimento, imprimindo, inclusive, seus próprios juizos de valor.Entre os brasileiros que vêm e vão encontram-se os cientistas sociais que transformam o movimento emobjeto de investigação. E é assim, através da produção de conhecimento informal, da imprensa e de intelectuais que sevaidescobrindo a magnitude do que se convencionou chamar de diáspora brasileira.

2) O único trabalho publicado sobre imigrantes brasileiros foi feito em Nova York pela socióloga Maxine Margolis (1994). O número 21 da revista Travessia do Centro de Estudos Migratórios é dedicado às mais recentes pesquisas sobre o tema (1995).

3) A pesquisa que orienta este artigo gerou minha dissertação de mestrado apresentada ao Programa de Pós-Graduação em Atropologia Social do Museu Nacional/UFRJ, sob orientação do Dr. João Pacheco de Oliveira Filho: "Quem Parte, Quem Fica: uma etnografia sobre imigrantes brasileiros em Londres", (1994).

4) Principalmente nas noites brasileiras promovidas por casas noturnas londrinas, nos concertos de cantores brasileiros, nos restaurantes brasileirose nas escolas de samba.

5) Anoção de "comunidade brasileira" é amplamente utilizada pelos brasileiros quando querem se definir como coletividade social em Londres e não carrega nenhuma conotação teórica neste texto.

6) Deve-se tomar cuidado com o uso das categorias de imigrante temporário e refugiado econômico na ivestigação sobre esta população em Londres, visto que estas são categorias utilizadas peloórgão britânico de controle da imigração (Home Office) para definir os imigrantes brasileiros. Do mesmo modo utilizam a idéia de que estes imigrantes não formam uma comunidade coesa. É importante perceber em que sentido determinadas categorias são usadas por organismos governamentais ao definirem populaçōes específicas. Para maiores detalhes sobre esta questão, no caso da relação entre os brasileiros e o controle britânico da imigração, vide Torresan, 1994.

7) Com o necessário recrutamento de mão-de-obra para os Estados mais industrializados da Europa, após a Segunda Guerra Mundial, houve intensa movimentação populacional dentro do continente europeu. Como a demanda de força de trabalho superou as possibilidades das fontes internas, os paises colonizadores incentivaram o processo migratório de suas colônias e territórios dependentes. Foi neste periodo que as grandes naçōes da Europa, cuja auto-representação era a de que se constituiam em paises de população homogênea, transformaram-se em Estados multirraciais. No entanto, a ideologia que dominava o processo de recrutamento, seja ele voluntário ou financiado pelo governo do país receptor, era a de que, tão logo não se fizessem mais necessários e em consequência do recrudescimento do mercado de trabalho interno, esses imigrantes seriam naturalmente repatriados. O maior problema desta ideologia era o de representar os imigrantes como recursos econômicos, ferramentas de reconstrução do pós-guerra, e esqueciam-se que estavam lidando com pessoas de carne e osso e que, sendo assim, viajavam levando não apenas seus braços para trabalhar, mas também uma importante bagagem de expectativas, valores, tradiçōes e planos de vida.

8) "Conjunto de Estados, territórios e protetorados que, oriundos do Império Britânico, reconhecem como seu chefe o soberano da Grã-Bretanha e se identificam por sua fidelidade comum à Coroa Britânica." (verbete in: Houaiss, 1980)

9) Esta situação de irregularidade nãoé atributoapenas dos imigrantes brasileiros, tampouco a natureza "aventureira" de seu empreendimento migratório, caracterizada pela imprevisibilidade do desenrolar de sua estadia. Na realidade Londres recebe pessoas originárias das mais diversas partes do mundo que ficam ai nesta mesma situação.

10) Job Centres são agências de emprego governamentais. Estas agências podem emitir permissão de trabalho para estudantes integrais que queiram trabaIhar por, no máximo, quinze horas semanais. A maior parte dos brasileiros que possuem visto de estudante, mesmo quando chegam a pedir tais permissōes ao Job Centre, trabalham muito mais do que este limite.

11) Os termos grifados referem-se a categorias frequentemente utilizadas por meus informantes.

\section{REFERÊNCIASBIBLIOGRÁFICAS}

- HOME OFFICE

1993 - Brasilian Nationals and UK Immigration Control, não publicado.

- HOUAISS, Antônio (dir.)

1980 - Pequeno Dicionário Enciclopédico Larrousse. Rio de Janeiro: Larrousse do Brasil.

- MARGOLIS, Maxine L.

1994 - Little Brasil. New Jersey: Princeton University Press.

- MOTTA, Edson

1991 - O Último que Sair Apaga a Luz: uma vida melhor na Europa e como chegar lá. São Paulo: publicação independente.

- TORRESAN, Angela

1994 - Quem Parte, Quem Fica: uma etnografia sobre imigrantes brasileiros em Londres. Dissertação de Mestrado não publicada, Museu Nacional, UFRJ.

- TRAVESSIA

1995 - São Paulo, CEM, Ano VIII, n 21, janeiro-abril. 